\title{
PENDETEKSIAN OBJEK ROKOK PADA VIDEO BERBASIS PENGOLAHAN CITRA DENGAN MENGGUNAKAN METODE HAAR CASCADE CLASSIFIER
}

\author{
Kadek Oki Sanjaya ${ }^{1}$, Gede Indrawan ${ }^{2}$, Kadek Yota Ernanda Aryanto ${ }^{3}$ \\ 1 Universitas Pendidikan Ganesha \\ 2 Universitas Pendidikan Ganesha \\ ${ }^{3}$ Universitas Pendidikan Ganesha
}

\begin{abstract}
Abstrak
Object detection is a topic widely studied by the scientists as a special study in image processing. Although applications of this topic have been implemented, but basically this technology is not yet mature, futher research is needed to developed to obtain the desired result. The aim of the present study is to detect cigarette objects on video by using the Viola Jones method (Haar Cascade Classifier). This method known to have speed and high accuracy because of combining some concept (Haar features, integral image, Adaboost, and Cascade Classifier) to be a main method to detect objects. In this research, detection testing of cigarettes object is in samples of video with the resolution $160 \times 120$ pixels, $320 \times 240$ pixels, 640x480 pixels under condition of on 1 cigarette object and condition 2 cigarettes object. The result of this research indicated that percentage of average accuracy highest $93.3 \%$ at condition 1 cigarette object and $86,7 \%$ in the condition 2 cigarette object that was detected on the video with resolution $640 \times 480$ pixels, while the percentage of accuracy lowest $90 \%$ at condition 1cigarette object, and $81,7 \%$ at the condition 2 cigarette objects, detected on the video with the lowest resolution 160x120 pixels. The percentage of average errors at detection cigarettes object was inversely with percentage of accuracy. So that the detection system is able to better recognize the object of the cigarette, then the number of samples in the database needs to be improved and able to represent various types of cigarettes under various conditions and can be added new parameters related to cigarette object.
\end{abstract}

\author{
Keywords: \\ Haar Cascade Classifier, \\ Deteksi Objek Rokok
}

\section{PENDAHULUAN}

Persebaran konten video yang memuat adegan orang merokok beredar begitu mudah dan cepat. Secara hukum, persebaran video dengan konten tersebut melanggar Peraturan Pemerintah Nomor 109 Tahun 2012 Republik Indonesia pasal 39 tentang perikalanan dan promosi rokok. Selain payung hukum, berbagai usaha telah dilakukan pemerintah untuk mengurangi persebaran video dengan konten yang tidak layak konsumsi untuk anak-anak, salah satunya adalah usaha preventif dengan penyaringan konten film sebelum layak tayang di televisi. Misalnya dengan memberikan efek blur pada adegan yang memuat adegan orang merokok. Namun ini dianggap kurang efisien karena itu bisa dilakukan dengan lebih cepat dengan menggunakan teknik pendeteksian dengan memanfaatkan algoritma Haar Cascades Classifier. Haar Cascade Classifier merupakan metode yang telah banyak diteliti, sebab metode ini mampu memberikan akurasi yang baik dalam pendeteksian objek. Dengan menggunakan sistem pendeteksi objek rokok diharapkan dapat dikembangkan kedalam berbagai sistem yang membutuhkan aspek pendeteksian objek rokok.

\section{METODE PENELITIAN}

Pengambilan dilakukan dengan mencari beberapa gambar di internet, jejaring sosial, mengambil foto secara langsung dengan menggunakan kamera handphone maupun kamera digital untuk dijadikan data training dan mengambil video dari internet, video diambil langsung dengan menggunakan kamera handphone maupun kamera digital untuk dijadikan sebagai data uji. 
Tahapan penelitian yang digunakan dalam perancangan sistem deteksi objek rokok dengan menggunakan metode Haarcascade Classifier dapat dilihat pada gambar 1 berikut ini.

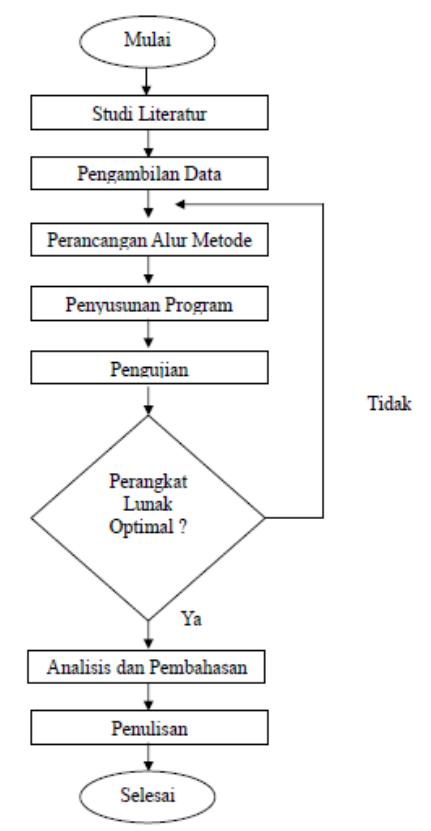

Gambar 1. Tahapan Penelitian

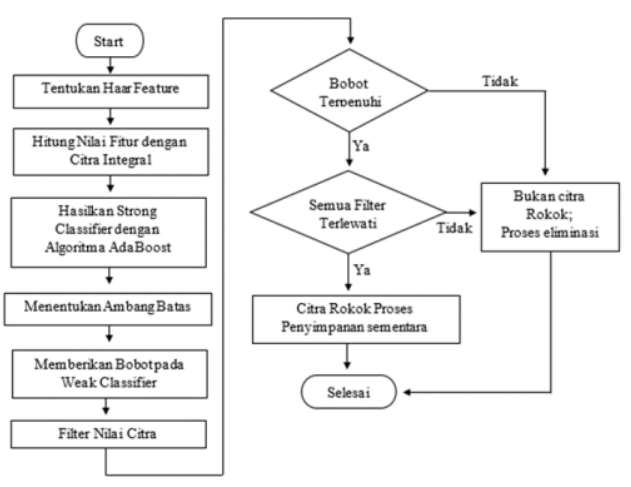

\section{Gambar 2. Rancangan Pendeteksian Objek Rokok}

Metode Haar Cascade Classifier menggunakan data latih dari citra-citra yang kurang tajam sebagai bagian dari proses pengklasifikasian citra. Klasifikasi citra dilakukan berdasarkan nilai dari sebuah fitur. keberadaan ada atau tidaknya fitur objek rokok ditentukan dengan mengurangi nilai pixel di wilayah gelap dengan nilai pixel di wilayah terang. Jadi setiap gambar dirubah kedalam warna hitam dan putih. Jika nilai dari hasil perbedaanya di atas dari ambang batas selama masa pembelajaran citra maka fitur tersebut dapat dikatakan ada.

Untuk memudahkan proses perhitungan nilai dari setiap fitur Haar pada setiap lokasi gambar dalam penelitian ini dilakukan proses pengintegralan citra. Secara umum integral mempunyai makna menambahkan bobot, bobot merupakan nilai-nilai piksel yang akan ditambahkan ke dalam gambar asli. Nilai integral dari setiap piksel merupakan jumlah dari semua piksel sebelah atasnya dan di sebelah kirinya. Keseluruhan gambar dapat diintegrasikan dengan operasi bilangan bulat per piksel. Sebagai 
simulasi sederhana dimisalkan terdapat citra input berukuran $5 \times 5$ dengan nilai masing-masing piksel seperti Gambar 3.

\begin{tabular}{|l|l|l|l|l|}
\hline 3 & 6 & 9 & 8 & 7 \\
\hline 9 & 2 & 7 & 1 & 9 \\
\hline 5 & 1 & 8 & 7 & 4 \\
\hline 2 & 4 & 2 & 5 & 9 \\
\hline 7 & 6 & 2 & 1 & 4 \\
\hline
\end{tabular}

Gambar 3

Contoh Citra Ukuran $5 \times 5$ piksel

(Mulyawati dan Bahar, 2014)

Berdasarkan Gambar 3, maka citra integralnya seperti pada Gambar 4.

\begin{tabular}{|l|l|l|l|l|}
\hline 3 & 9 & 18 & 26 & 33 \\
\hline 12 & 20 & 36 & 45 & 61 \\
\hline 17 & 26 & 50 & 66 & 86 \\
\hline 19 & 32 & 58 & 79 & 108 \\
\hline 26 & 45 & 73 & 95 & 128 \\
\hline
\end{tabular}

Gambar 4

Citra Integral Ukuran $5 \times 5$ piksel

(Mulyawati dan Bahar, 2014)

Untuk mengetahui pada setiap elemen matriks dapat dijelaskan pada Gambar 5.

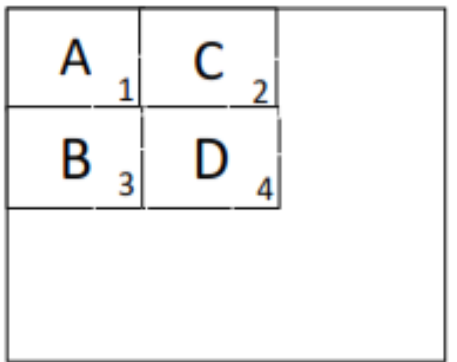

Gambar 5

Contoh Pengambilan Piksel

(Mulyawati dan Bahar, 2014)

Berdasarkan pada Gambar 3.7, nilai piksel D pada citra integral adalah D $=4+1-(2+3)$. Dimana angka 1-4 merupakan indeks dari nilai masing-masing piksel pada citra A-D menunjukkan posisi piksel.

Contoh 1, perhatikan Gambar 6 (berdasarkan hasil citra integral pada gambar 3): 


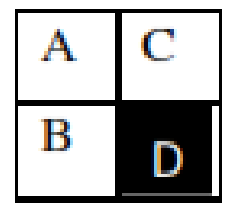

Gambar 6

Contoh Pengambilan Piksel

(Mulyawati dan Bahar, 2014)

Nilai piksel pada citra integral dari Gambar 6 dilihat pada Gambar 7.

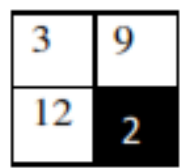

Gambar 7

Nilai Piksel Citra Integral

(Mulyawati dan Bahar, 2014)

Nilai piksel pada daerah hitam $=D+A-(B+C)=20+3-(12+9)=2$

Buktinya dilihat pada citra asli pada Gambar 3. Nilai piksel pada daerah hitam $=2$

Algoritma AdaBoost bertujuan mengkombinasikan banyak citra-citra yang kurang tajam (weak classifiers) untuk menjadi citra-citra yang lebih tajam (strong classifiers) dengan memberi bobot kepada citra weak classifiers.

Cascade classifier melakukan proses dari banyak fitur-fitur yang diorganisir dengan bentuk klasifikasi bertingkat. Terdapat tiga buah klasifikasi untuk menentukan apakah benar atau tidak ada fitur rokok pada fitur yang sudah dipilih. Pada klasifikasi filter pertama, tiap subcitra akan diklasifikasi menggunakan satu fitur. Jika hasil nilai fitur dari filter tidak memenuhi kriteria yang diinginkan, hasil tersebut akan ditolak. Algoritma kemudian bergerak ke sub-window selanjutnya dan menghitung nilai fitur kembali. Jika didapat hasil sesuai dengan threshold yang diinginkan, maka dilanjutkan ke tahap filter selanjutnya. Hingga jumlah sub-window yang lolos klasifikasi akan berkurang hingga mendeteksi image yang dideteksi. Pada gambar 4.11 merupakan proses rangkaian filter yang dilalui oleh setiap klasifier.

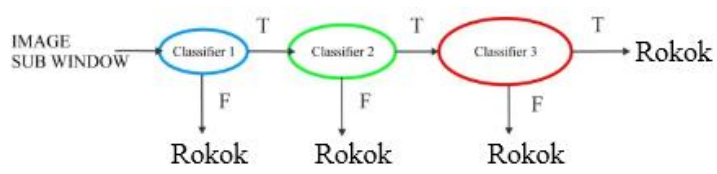

Gambar 4.1

\section{Cascade Classifer}

(Amalga, 2015)

1. Pada filter pertama dipilih satu fitur klasifier dengan persentase tingkat pendeteksian sebesar $100 \%$ dan sekitar 50\% tingkat kesalahan.

2. Pada filter kedua dipilih lima buah fitur klasifier dengan persentase tingkat pendeteksian sebesar $100 \%$ da $40 \%$ tingkat kesalahan (20\% kumulatif).

3. Pada filter ketiga dipilih 20 fitur klasifier dengan persentase tingkat pendeteksian sebesar $100 \%$ dengan tingkat kesalahan sebesar $100 \%$ (2\% kumulatif).

Setelah dilakukan serangkaian proses seperti pemilihan fitur dan klasifikasi bertingkat maka akan didapatkan sebuah hasil pendeteksian. Hasil pendeteksian bisa berupa rokok atau bukan rokok. Pada saat proses klasifikasi bertingkat dilakukan, maka pada image tersebut akan ditandai dengan sebuah rectangle 
pada daerah rokok yang terdeteksi. Pada Gambar 7 di bawah ini merupakan contoh hasil pendeteksian dari proses akhir deteksi objek rokok dengan algoritma Haar cascade classifier.

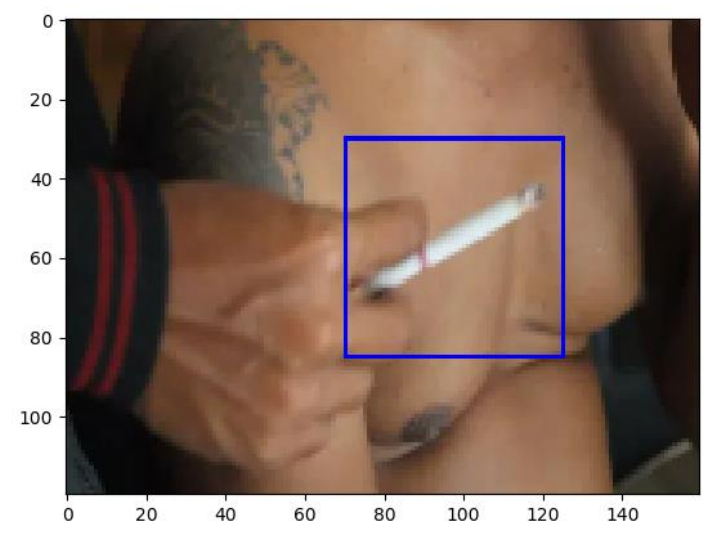

Gambar 7

Hasil Pendeteksian

\section{ANALISIS DAN PEMBAHASAN}

Penerapan metode Haar Cascade Classifier berdasarkan dari tahapan penelitian yang dimulai dengan membuat file cascade.xml yang dibuat dengan melakukan proses training 254 gambar positif rokok dan 508 gambar negative rokok. Gambar positif rokok berarti gambar yang memang benar-benar berisi rokok dengan ukuran pixel 100x100. Sedangkan gambar negative rokok berisi gambar yang tidak ada rokok dengan ukuran pixel 150x150.

Tahap selanjutnya yang dilakukan pada penelitian ini adalah mengekstrak video uji menjadi frame. Tujuan dari ekstraksi ini adalah untuk memperoleh gambar atau citra untuk masuk pada proses pendeteksian.

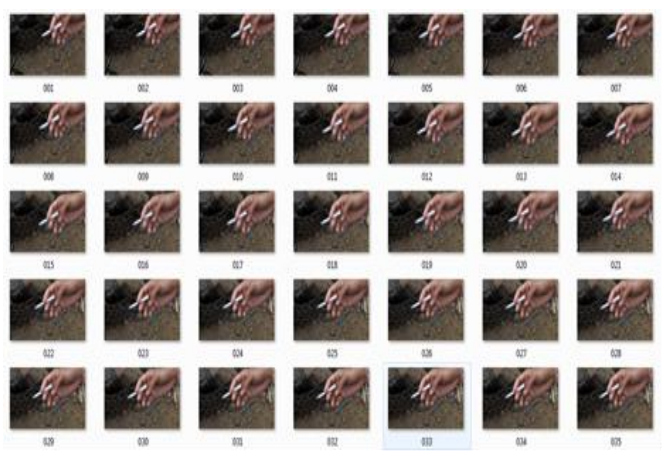

Gambar 9

Ekstrak Video menjadi Frame

Pada proses pendeteksian objek rokok dengan menggunakan metode Haar cascade classifier, ada beberapa proses yang dilakukan sebelum akhirnya akan menghasilkan sebuah output objek rokok yang terdeteksi pada sebuah video. Dalam deteksi objek rokok, proses-proses tersebut yaitu Preprocessing, Haar-Like Feature, Integral image, AdaBoost (Adaptive Boosting), Cascade Classifier, dan Combine frame to video seperti pada skema deteksi objek rokok yang dijelaskan pada bab sebelumnya. Skema proses dari tiap-tiap tahap yang dilalui oleh citra untuk memperoleh hasil pendeteksian objek rokok dapat dilihat pada Gambar 10. 


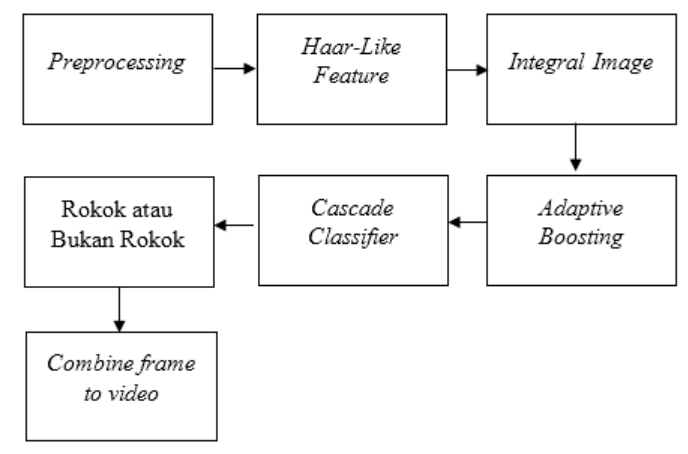

Gambar 10

Skema Deteksi Objek Rokok

(Amalga, 2015)

PERSENTASE RATA-RATA KEAKURATAN SISTEM DETEKSI OBJEK ROKOK

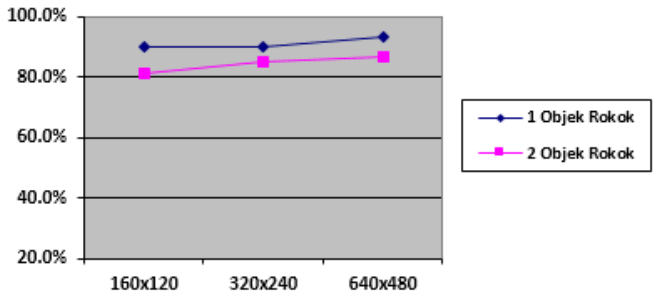

Gambar 11

Grafik persentase rata-rata keakuratan sistem deteksi

\section{PERSENTASE RATA-RATA KESALAHAN SISTEM DETEKSI OBJEK ROKOK}

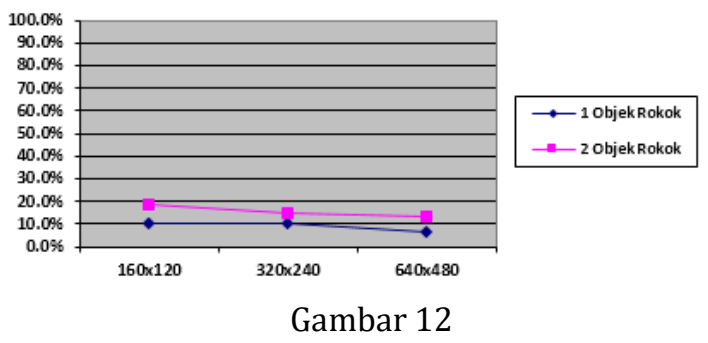

Grafik persentase rata-rata kesalahan sistem deteksi

Pada Gambar 11 menunjukkan data grafik persentase rata-rata keakuratan deteksi objek rokok, dengan database properties, file name: cascade, type of file: .xml, Size: $29 \mathrm{~Kb}$ dengan Num cascade stages (NCS): 10 stages, pada video dengan resolusi berdeda dari 160x120 piksel, 320x240 piksel dan 640x480 piksel pada kondisi 1 objek rokok dan 2 objek rokok.

Persentase rata-rata kekauratan tertinggi pada grafik tersebut adalah 93,3\% pada kondisi 1 objek rokok dan 86,7\% pada kondisi 2 objek rokok, terdeteksi pada video dengan resolusi 640x480 piksel. Sedangkat rata-rata keakuratan terendah 90\% pada kondisi 1 objek rokok, dan 81,7\% pada kondisi 2 objek rokok, terdeteksi pada video dengan resolusi terendah 160x120 piksel. Pada persentase rata-rata kesalahan pada grafik Gambar 12 berbanding terbalik dengan parameter persentase keakuratan deteksi objek rokok. Persentase tertinggi adalah $10 \%$ pada kondisi 1 objek rokok dan 18.3\% pada kondisi 2 objek rokok, terdapat pada video dengan resolusi $160 \times 120$ piksel. Sebaliknya persentase kesalahan terendah 6,7\% pada kondisi 1 objek rokok, dan 13,3\% pada kondisi 2 objek rokok, terdeteksi pada video dengan resolusi $640 \times 480$ piksel. 
Kondisi ini menunjukkan adanya kualitas resolusi yang merupakan suatu kondisi dinamis dari sebuah citra dengan resolusi tertentu, yang dalam hal ini bergantung pada banyaknya titik untuk setiap satuan (dot per inch) yang terdapat dalan citra tersebut.

Kualitas resolusi dikatakan baik jika citra tersebut memiliki resolusi yang besar, dimana semakin besar resolusi makin banyak titik yang terkandung dalam citra sehingga menjadi lebih luas dalam visualisasinya (Hestiningsih, 2008).

Menurutnya kualitas resolusi yang dihasilkan, resolusi dibedakan menjadi: 1) Resolusi Tinggi (High Resolution): Suatu citra dikatakan memiliki resolusi tinggi jika tingkat ketelitian yang cukup tinggi dari suatu media dalam menangkap ataupun menampilkan datanya, 2) Resolusi Rendah (Low Resolution): Citra dikatakan memiliki resolusi rendah jika pada layar atau gambar yang teks grafiknya tampil dengan detail yang relatif kasar.

Berdasarkan dengan kondisi tersebut, jika dibandingkan dengan kondisi 1 objek rokok atau 2 objek rokok, dengan database yang sama untuk mendeteksi objek rokok dari grafik Gambar 11 persentase keakuratan dan grafik Gambar 12 persentase kesalahan maka dapat disimpulkan bahwa selain spesifikasi parameter database, ukuran resolusi pada citra video yang dideteksi juga mempengaruhi hasil perhitungan keakuratan dan kesalahan dalam mendeteksi objek rokok.

\section{KESIMPULAN}

Kesimpulan dari penelitian ini adalah sebagai berikut:_Pendeteksian objek dengan menggunakan metode Haar Cascade Classifier mampu memberikan akurasi yang baik dalam mendeteksi objek rokok. Hasil deteksi pada sampel video dengan resolusi $160 \times 120$ piksel, 320x240 piksel, 640x480 piksel diperoleh persentase keakuratan tertinggi pada deteksi objek rokok 93\% pada kondisi 1 objek rokok dan 86,7\% pada kondisi 2 objek rokok yang terdeteksi pada video dengan resolusi 640x480 piksel, sedangkan diperoleh persentase keakuratan terendah pada deteksi objek rokok 90\% pada kondisi 1 objek rokok, dan 81,7\% pada kondisi 2 objek rokok, terdeteksi pada video dengan resolusi terendah 160x120 piksel berbanding terbalik dengan parameter persentase keakuratan masing-masing deteksi.

Berdasarkan simpulan tersebut dapat dikatakan bahwa hasil dari penelitian ini dapat digunakan sebagai referensi untuk penerapan metode Haar Cascade Classifier pada citra digital, untuk mendeteksi objek rokok pada video.

Saran: Agar sistem pendeteksi mampu mengenali objek rokok dengan lebih baik, maka jumlah sampel dalam database perlu ditingkatkan dan mampu mewakili berbagai jenis rokok dalam berbagai kondisi. Perlu dilakukan penelitian lebih lanjut dengan menambahkan beberapa parameter tambahan yang berkaitan dengan objek rokok, sehingga kelak mampu memberikan hasil yang lebih baik dalam mendeteksi objek rokok.

\section{DAFTAR PUSTAKA}

Amalga, SG. 2015. http://repository.unpas.ac.id/26827/6/.(diakses pada tanggal 10 januari 2017).

Anaconda. 2017. https://anaconda.org/anaconda/spyder. (diakses pada tanggal 6 Januari 2017).

Arihutomo, Mukhlas. 2010. "Rancang Bangun Sistem Penjejakan Objek Menggunakan Metode Viola Jones Untuk Aplikasi EyeBot”. http://repo.pens.ac.id/311/1/1151.pdf. (diakses tanggal 5 Januari 2017).

Baser, Ekrem. 2016. "Detection and Classification Of Vehicles In Traffic By Using Haar Cascade Classifier", Proceedings of 58th ISERD International Conference, Prague, Czech Republic, 23rd-24th December 2016, www.worldresearchlibrary.org/up_proc/pdf/578-1486634118 19-22.pdf. (diakses tanggal 8 Januari 2017).

Doxygen. 2012. http://docs.opencv.org/trunk/d7/d8b/ tutorial_py_face_detection.html. (diakses tanggal 6 Januari 2017).

Harrison. 2017. https://pythonprogramming.net/haar-cascade-object-detection-python-opencv-tutorial/. (diakses tanggal 6 Januari 2017).

Hestiningsih, I. 2008. Pengolahan Citra. http://toba.mytoba.com/dl/Pengolahan\% 20Citra.pdf. (diakses tanggal 4 Januari 2017). 
Kurniawan, Agus. 2009. "Aplikasi Absensi Kuliah Berbasis Identifikasi Wajah Menggunakan Metode Gabor Wavelet" Makalah Skripsi Institut Teknologi Sepuluh Nopember (ITS) Surabaya, Surabaya.

Mahmudi, Ali dan M. Taufiqur Rusda. 2014. "Deteksi Senjata Tajam dengan metode Haar Cascade Classifier Menggunakan Teknologi SMS Gateway". https://www.academia.edu/. (diakses tanggal 3 Januari 2017).

Muhaimin, Syahlan. 2013. "Rancang Bangun Aplikasi Multi-Face Detector menggunakan Metode Viola Jones pada Face Recognitioon”. http://repository.uin-suska.ac.id/1220 /1/2013_2013126TIF.pdf. (diakses tanggal 6 Januari 2017).

Mulyawati, Anizsah dan Chaerunisai Bahar. 2014. "Metode Viola-Jones untuk Mendeteksi Jenis dan Jumlah Kendaraan dalam Intelligent Transport System". Makalah Skripsi Jurusan Teknik Elektro Universitas Hasanuddin. Makassar.

Munir, Rinaldi. 2004. Pengolahan Citra Digital. Bandung: Unit Penerbitan Informatika Bandung.

Padilla, R. 2012. "Evaluation of Haar Cascade Classifiers Designed for Face Detection". International Journal of Computer, Electrical, Automation, Control and Information Engineering Vol:6, No:4, 2012.

Priawadi. 2012. http://www.priawadi.com/2012/09/ opencv.html. (diakses pada tanggal 5 April 2017).

Reinius, Staffan. 2013. "Object Recognition using the OpenCV Haar Cascade-Classifier on the iOS platform". http://www.diva-portal.org/smash/get/diva2:601707/fulltext 01.pdf. (diakses pada tanggal 6 Januari 2017).

Robin. 2013. http://coding-robin.de/2013/07/22/train-your-own-opencv-haar-classifier.html (diakses pada tanggal 5 Januari 2017).

Santoso, Hadi dan Agus Harjoko. 2013. Haar Cascade Classifier dan Algoritma untuk Deteksi Banyak Wajah dalam Ruang Kelas. Jurnal Teknologi, Volume 6 Nomor 2, hlm 108-115.

Seo, Naotoshi. 2007. Tutorial: OpenCV haartraining (Rapid Object Detection with A Cascade of Boosted Classifiers Based on Haar-like Feature). http://note.sonots.com/SciSoftware/ haartraining.html. (diakses pada tanggal 10 Januari 2017).

Soo, Sander. 2014. "Object detection using Haar-cascade Classifier", http://ds.cs.ut.ee/Members/artjom85/2014dss-coursemedia/Object\%20detection\%20using\%20Haar-final. pdf. (diakses pada tanggal 7 Januari 2017).

Taurisna, Afnisyah. 2009. Analisis Pengaruh Kualitas Citra terhadap Kinerja Metode Pendeteksi Tepi. http://repository.usu.ac.id/handle/123456789/7873. (diakses pada tanggal 7 Januari 2017.

Viola, Paul and Michael Jones. 2001. "Rapid Object Detection using a Boosted Cascade of Simple Features". Proceedings of the 2001, IEEE Computer Society Conference on, 2001, vol. 1, pp. I-511.

Yildirim, Mustafa E. 2014. "Gender Classification Based on Binary Haar Cascade”, International Journal of Computer and Communication Engineering, Vol. 3, No. 2, Maret 2014. 